\title{
Study of serum calcidiol level in pregnancy and its association with fetal outcome
}

\author{
Suman Kumari Pandey ${ }^{1}$, Hari Shankar Pandey ${ }^{2, *}$, Vinita Kalra ${ }^{3}$ \\ ${ }^{\mathbf{1}}$ Assistant Professor Dept. of Biochemistry, Government Doon Medical College, Dehradun, Uttarakhand, ${ }^{2}$ Associate Professor, \\ Dept. of Pathology, Government Doon Medical College, Dehradun, Uttarakhand, ${ }^{3}$ Professor, Dept. of Biochemistry, Himalayan \\ Institute of Medical Sciences, Dehradun, Uttarakhand, India
}

*Corresponding Author:

Email: physianin@yahoo.com

Received: $18^{\text {th }}$ March, 2018

Accepted: $28^{\text {th }}$ April, 2018

\begin{abstract}
Introduction: Presently there are no guidelines for routine screening of vitamin D deficiency in antenatal women, therefore this study was planned to find the association of maternal vitamin D level with fetal outcomes.

Materials and Methods: The subjects were 100 pregnant women between 12 to 24 weeks of gestation selected from Obstetrics and Gynecology OPD. In the total number of subjects, serum 25 hydroxyvitamin D [25(OH) D] level was estimated by direct ELISA method and its association with fetal outcome - birth weight, length, head circumference and knee-heel length was studied.

Results and Conclusion: In the present study a significant association was found between maternal vitamin D status and neonatal birth weight but not with other birth parameter.
\end{abstract}

Keywords: Maternal Vit D, Birth weight.

\section{Introduction}

Pregnancy is the fertilization and development of one or more offsprings, known as an embryo or fetus, in the womb of a woman. A balanced, nutritious diet of carbohydrates, fats and proteins is an important aspect of a healthy pregnancy and ensures good nutrition. Several micronutrients are important for the health of the developing fetus, especially in areas of the world where insufficient nutrition is prevalent. Among these micronutrients vitamin $\mathrm{D}$ and calcium play an important role in bone development and may require to be supplemented. ${ }^{1,2}$ The discovery of multiple functions of vitamin D that are important for growth and development, including regulation of cellular differentiation, apoptosis, immune system development and brain development has led to increased interest in the role of this vitamin during pregnancy. ${ }^{3-5}$ Studies have explored the association between maternal vitamin $\mathrm{D}$ status measured in pregnancy with birth weight, small-for -gestational age (SGA) infants and postnatal growth (weight and length), as well as the potential role of vitamin D status in respiratory infections, seizures and childhood outcomes. ${ }^{6}$

Vitamin D deficiency is prevalent in India which is unexpected in a tropical country such as India, where there is abundant overhead sun for most part of the year, nevertheless, hypovitaminosis $\mathrm{D}$ has been observed in India. ${ }^{7}$

Presently there are no guidelines for routine screening of vitamin D deficiency in antenatal women, therefore this study was planned to find the association of maternal vitamin D level with fetal outcomes.

\section{Materials and Methods}

In the present study subjects were 100 pregnant women between 12 to 24 weeks of gestation selected from Obstetrics and Gynecology. Prior approval from ethical committee was obtained and written informed consent of the pregnant women were taken before collection of the data. In the total number of subjects, serum 25-hydroxyvitamin $\mathrm{D}[25(\mathrm{OH}) \mathrm{D}]$ level was estimated by direct ELISA method. As per the kit (DRG 25(OH)D vitamin D total ELISA, EIA 5396, Germany) which was used for the estimation of serum $25(\mathrm{OH}) \mathrm{D}$, the cut-off level for vitamin D deficiency was taken to be $<75 \mathrm{nmol} / \mathrm{L}$. Levels of $25(\mathrm{OH}) \mathrm{D}$ and its association with fetal outcome - birth weight, length, head circumference and knee-heel length was studied. Data collected were subjected to statistical analysis, with the help of Epi info software, $7^{\text {th }}$ version.

Descriptive statistics were expressed as percentage, means and standard deviation.

Chi-square test (with fisher exact test and yate correction was done wherever required) to find the association between vitamin $\mathrm{D}$ levels and various variables.

Independent ' $t$ ' test of significance was used to analyze the significance between birth measures (neonatal length, head-circumference and knee-heel length) and vitamin D levels.

\section{Results}

Results are depicted in Tables 1-3. Out of the 23 women who delivered preterm babies, 21 women (i.e. $91.30 \%)$ had serum $25(\mathrm{OH})$ D levels lower than $75 \mathrm{nmol} / \mathrm{L}$. The other 2 women (i.e. $8.69 \%$ ) who also 
had preterm deliveries, had normal serum $25(\mathrm{OH}) \mathrm{D}$ levels $>75 \mathrm{nmol} / \mathrm{L}$.

77 of the study subjects gave birth at term. 67 of these women (i.e. $87.01 \%$ ) had serum $25(\mathrm{OH}) \mathrm{D}$ levels $<75 \mathrm{nmol} / \mathrm{L}$ and 10 women (i.e. $12.98 \%$ ) had serum 25(OH)D levels $>75 \mathrm{nmol} / \mathrm{L}$. The difference however, was not statistically significant. (Table 1)

Of the 88 vitamin $\mathrm{D}$ deficient women, 44 women (i.e. 50\%) had babies with normal birth weight (i.e. $>2.5 \mathrm{~kg}$ ). However, the same number and percent of these women also gave birth to low birth weight babies with birth weight $<2.5 \mathrm{~kg}$.

2 out of the 12 study subjects (i.e. $16.66 \%$ ) who were vitamin D sufficient also gave birth to low birth weight neonates. The other 10 women (i.e. $88.33 \%$ ) had babies with normal birth weight. (Table 2)
On analysis, association between serum $25(\mathrm{OH}) \mathrm{D}$ levels and neonatal birth weight was found to be statistically significant $(\mathrm{p}=0.03)$.

In the total number of studied subjects, 88 women were found to be vitamin D deficient $(<75 \mathrm{nmol} / \mathrm{L})$. The mean birth variables i.e. length, head circumference and knee-heel length of the neonates born to these deficient women were found to be $48.88 \pm 1.27 \mathrm{~cm}, 34.04 \pm 0.83$ $\mathrm{cm}$ and $11.04 \pm 0.90 \mathrm{~cm}$, respectively.

The mean birth variables of the neonates born to mothers having normal vitamin D levels $(>75 \mathrm{nmol} / \mathrm{L})$ were found to be, length $49.33 \pm 1.15 \mathrm{~cm}$, head circumference $34.25 \pm 0.69 \mathrm{~cm}$ and knee-heel length $11.24 \pm 0.70 \mathrm{~cm}$.

On analysis, association between serum 25(OH)D levels with birth variable was not found to be statistically significant. (Table 3)

Table 1: Gestational age and serum vitamin 25(OH)D levels (n=100)

\begin{tabular}{|c|c|c|c|c|}
\hline Gestational age & $\begin{array}{c}\text { Number } \\
\text { of subjects }\end{array}$ & $\begin{array}{c}\text { Maternal serum } \\
\text { level 25(OH)D } \\
(<75 \mathrm{nmol} / \mathrm{L}) \\
\end{array}$ & $\begin{array}{c}\text { Maternal serum } \\
\text { level } 25(\mathrm{OH}) \mathrm{D} \\
(>75 \mathrm{nmol} / \mathrm{L})\end{array}$ & $\begin{array}{c}\text { Chi-square } \\
\text { p value }\end{array}$ \\
\hline $\begin{array}{l}\text { Preterm delivery } \\
\text { (<37weeks) }\end{array}$ & 23 & $\begin{array}{c}21 \\
(91.30 \%)\end{array}$ & $\begin{array}{c}2 \\
(8.69 \%)\end{array}$ & \multirow{2}{*}{$\begin{array}{c}\chi 2=0.309 \\
\text { d.f }=1 \\
p=0.578\end{array}$} \\
\hline $\begin{array}{l}\text { Term delivery } \\
\text { (> } 37 \text { weeks ) }\end{array}$ & 77 & $\begin{array}{c}67 \\
(87.01 \%)\end{array}$ & $\begin{array}{c}10 \\
(12.98 \%)\end{array}$ & \\
\hline
\end{tabular}

Table 2: Comparison of serum $25(\mathrm{OH}) \mathrm{D}$ level with neonatal birth weight $(\mathrm{n}=100)$

\begin{tabular}{|l|c|c|c|c|}
\hline $\begin{array}{c}\text { Serum } \\
\text { 25(OH)D Levels }\end{array}$ & $\begin{array}{c}\text { Number } \\
\text { of subjects }\end{array}$ & $\begin{array}{c}\text { Low birth weight } \\
(<\mathbf{2 . 5} \mathbf{~ k g})\end{array}$ & $\begin{array}{c}\text { Normal birth } \\
\text { weight }(>\mathbf{2 . 5} \mathbf{k g})\end{array}$ & $\begin{array}{c}\text { Chi square } \\
\text { p value }\end{array}$ \\
\hline $\begin{array}{l}\text { Serum 25(OH)D } \\
\text { <75nmol/L }\end{array}$ & 88 & 44 & 44 & \\
& & $(50 \%)$ & $(50 \%)$ & $\chi 2=4.72$ \\
Serum 25(OH)D & 12 & 2 & 10 & $\mathrm{~d} . \mathrm{f}=1$ \\
$>75 \mathrm{nmol} / \mathrm{L}$ & & $(16.66 \%)$ & $(83.33 \%)$ & $\mathrm{p}=0.03$ \\
\hline
\end{tabular}

Table 3: Serum 25(OH)D levels with other neonatal birth variables $(n=100)$

\begin{tabular}{|l|c|c|c|c|}
\hline $\begin{array}{c}\text { Serum } \\
\mathbf{2 5}(\mathbf{O H}) \mathbf{D} \\
\text { Levels }\end{array}$ & $\begin{array}{c}\text { Number } \\
\text { of subjects }\end{array}$ & $\begin{array}{c}\text { Neonatal } \\
\text { Length }(\mathbf{c m}) \\
\text { Mean } \pm \text { SD }\end{array}$ & $\begin{array}{c}\text { Neonatal } \\
\text { Head circumference } \\
(\mathbf{c m}) \text { Mean } \pm \text { SD }\end{array}$ & $\begin{array}{c}\text { Neonatal knee-heel } \\
\text { length }(\mathbf{c m}) \\
\text { Mean } \pm \text { SD }\end{array}$ \\
\hline Serum 25(OH)D & 33 & 48.88 & 34.04 & 11.04 \\
$<75 \mathrm{nmol} / \mathrm{L}$ & & $( \pm 1.27)$ & $( \pm 0.83)$ & $( \pm 0.90)$ \\
\hline Serum $25(\mathrm{OH}) \mathrm{D}$ & 12 & 49.33 & 34.25 & 11.24 \\
$>75 \mathrm{nmol} / \mathrm{L}$ & & $( \pm 1.15)$ & $( \pm 0.69)$ & $( \pm 0.70)$ \\
\hline p- value & & 0.248 & 0.406 & 0.461 \\
$95 \% \mathrm{CI}$ & $(-1.21$ to 0.31$)$ & $(-0.70$ to 0.28$)$ & $(-0.73$ to 0.33$)$ \\
\hline
\end{tabular}

\section{Discussion}

Vitamin D has been a topic of concern in the medical world for the last 15 years. This has resurfaced in medical and scientific literature owing to its multiple effects on human health. Vitamin $D$ has been traditionally named the "Sunshine Vitamin", however, its deficiency is an unrecognized epidemic common among children, adults and pregnant women throughout the world, across all ethnicity and seasons. ${ }^{8}$

In this study out of the total number of studied pregnant women, $88 \%$ were found to be vitamin D deficient $(<75 \mathrm{nmol} / \mathrm{L})$, with mean serum level of vitamin $\mathrm{D}$ being $41.10 \pm 13.19 \mathrm{nmol} / \mathrm{L}$ whereas only $12 \%$ of the women were found to have normal vitamin D level (>75 nmol/L), with mean serum vitamin D level $105.06 \pm 46.70 \mathrm{nmol} / \mathrm{L}$.

Farrant et al and Sahu et al, in their studies on pregnant Indian women, found the prevalence of vitamin $\mathrm{D}$ deficiency to be $66 \%$ and $74 \%$ respectively. ${ }^{9,10}$ These studies highlighted high prevalence of vitamin D deficiency in pregnant ladies, inspite of adequate sunshine in our country. 
Sachan et al, in their study included a total number of 246 pregnant women. They found maternal serum $25(\mathrm{OH}) \mathrm{D}$ level to be $<10 \mathrm{ng} / \mathrm{ml}$ in 88 women out of 246 pregnant women (i.e $35.77 \%$ ) and to be $<15 \mathrm{ng} / \mathrm{ml}$ in 138 women out of 246 women (i.e 56.09\%). Cord blood, $25(\mathrm{OH}) \mathrm{D}$ level was found to be low $(5.2 \pm 3.0$ $\mathrm{ng} / \mathrm{ml}$ ) in those neonates born to mothers having $25(\mathrm{OH}) \mathrm{D}$ level $<10 \mathrm{ng} / \mathrm{ml}$. The cord blood level was also found to be low $(11.8 \pm 5.7 \mathrm{ng} / \mathrm{ml})$ in those neonates born to mothers having 25(OH)D level $<15 \mathrm{ng} / \mathrm{ml}$. Therefore, maternal serum $25(\mathrm{OH}) \mathrm{D}$ showed a significant positive correlation with cord blood. They also compared the serum 25(OH)D level in urban and rural pregnant women. In the urban group, 118 women out of 140 women (i.e $84 \%$ ). ${ }^{7}$

In this study, out of 23 mothers who delivered preterm babies, $21(91.30 \%)$ mothers were vitamin D deficient $<75 \mathrm{nmol} / \mathrm{L}$ and only $2(8.69 \%)$ mothers had normal vitamin D levels $>75 \mathrm{nmol} / \mathrm{L}$. Out of 77 term deliveries, $67(87.01 \%)$ of the mothers were vitamin D deficient $<75 \mathrm{nmol} / \mathrm{L}$, and 10 had normal vitamin D levels $>75 \mathrm{nmol} / \mathrm{L}$. But no significant association was found between maternal serum vitamin D level and gestational age. This finding is comparable to the study done on 221 Canadian women, in which no association was found between maternal vitamin D deficiency $(<50 \mathrm{nmol} / \mathrm{L})$ and gestational age. ${ }^{11}$ In another study done in North Carolina, preterm births were found in 40 cases of pregnant women, who were vitamin D deficient $(<50 \mathrm{nmol} / \mathrm{L})$. They also did not find any significant difference between maternal vitamin D level and gestational age. ${ }^{12}$

However, Morley et al, in their study found vitamin $\mathrm{D}$ deficiency $(<28 \mathrm{nmol} / \mathrm{L})$ in $7.2 \%(\mathrm{n}=27 / 374)$ of the pregnant women at $28-32$ weeks, and $6.4 \%$ $(n=23 / 359)$ of the women were deficient in vitamin $D$ at the time of recruitment. Babies of mothers in the low vitamin D group had mean gestational length 0.7 weeks shorter than babies of mother with vitamin $\mathrm{D} \geq 28$ $\mathrm{nmol} / \mathrm{L}$. In their study also no association between maternal vitamin D level and gestational age was found..$^{13}$ This finding is in concordance with the present study in which no statistically significant difference was observed between vitamin D levels and gestational age.

From pathological point of view there are numerous reasons for preterm births. One major cause is bacterial vaginosis. Anaerobic bacteria if present in the vagina is responsible for the release of inflammatory Cytokines and Prostaglandin $\mathrm{A}_{2}$, which disturbs the vaginal flora and leads to preterm delivery. Since vitamin D has an immunomodulatory and antiinflammatory effect, it prevents microbial invasion. Therefore vitamin $\mathrm{D}$ is thought to play a protective role in preterm delivery. ${ }^{14}$

In our study, $88 \%$ of the women were found to be vitamin D deficient $<75 \mathrm{nmol} / \mathrm{L}$ and only $12 \%$ of the pregnant women had vitamin $\mathrm{D}$ level $>75 \mathrm{nmol} / \mathrm{L}$.
Exactly half of the vitamin D deficient mothers, $50 \%$ $(\mathrm{n}=44 / 88)$ delivered neonates with birth weight $<2.5 \mathrm{~kg}$ and the other half $(n=44 / 88)$ had neonates with birth weight $>2.5 \mathrm{~kg}$. Whereas in vitamin $\mathrm{D}$ sufficient $(>75 \mathrm{nmol} / \mathrm{L})$ women only $16.66 \% \quad(\mathrm{n}=2 / 12)$ of the neonates were found to have low birth weight $(<2.5 \mathrm{~kg})$ and $83.33 \%(n=10 / 12)$ of the neonates were found to have normal birth weight $(>2.5 \mathrm{~kg})$.

The mean birth weight of neonates born to mothers having sufficient vitamin D was $2.58 \pm 0.39 \mathrm{~kg}$ and the mean birth weight of neonates born to the mothers having vitamin D deficiency was $2.48 \pm 0.60 \mathrm{~kg}$. Statistically significant association between maternal serum vitamin $\mathrm{D}$ and neonatal birth weight was found $(\mathrm{p}=0.03)$.

This study is comparable to study done by Bowyer et al, who found $15 \%$ of the pregnant women to be vitamin $\mathrm{D}$ deficient $(<25 \mathrm{nmol} / \mathrm{L})$ and $11 \%$ of the neonates to be deficient in vitamin $\mathrm{D}(<25 \mathrm{nnmol} / \mathrm{L})$. They found the birth weight to be lower among infants of vitamin D deficient against sufficient mothers, the mean birth weight being $3.24 \pm 5.45 \mathrm{gms}$ and 3.45 $\pm 5.55 \mathrm{gms}$ respectively $(\mathrm{p}<0.001)$. They also found that maternal vitamin D deficiency increases the risk of neonatal vitamin $\mathrm{D}$ deficiency. ${ }^{15}$

In the study mean neonatal length, head circumference and knee- heel length of neonates born to vitamin $\mathrm{D}$ deficient mothers, were found to be 48.88 $\pm 1.27 \mathrm{~cm}, \quad 34.4 \pm 0.83 \mathrm{~cm}$ and $11.04 \pm 0.90 \mathrm{~cm}$ respectively. In neonates born to mothers having sufficient vitamin D level, the birth variables i.e. neonatal length, head circumference and knee-heel length were found to be $49.33 \pm 1.5 \mathrm{~cm}, 34.25 \pm 0.69 \mathrm{~cm}$ and $11.24 \pm 0.70 \mathrm{~cm}$. Although no significant association was found between maternal vitamin D levels and the birth variables. However the mean level of the birth variables were lower in the neonates born to vitamin $\mathrm{D}$ deficient mothers.

Morley et al in their study done in Melbourne, found $7.2 \%$ of women to be vitamin $\mathrm{D}$ deficient $(<28 \mathrm{nmol} / \mathrm{L})$. The knee-heel length was found to be 4.3 $\mathrm{mm}$ lower $(95 \% \mathrm{CI},-7.3$ to 1.3$)$ in infants of mother with low vitamin D. After adjustment for gestational length, the difference was reduced to $2.7 \mathrm{~mm}(95 \% \mathrm{CI}$, -5.4 to 0.2$)(16)$. This study is in contrast to the present study in which no such difference was observed.

\section{Conclusion}

In the present study a significant association was found between maternal vitamin D status and neonatal birth weight but not with other birth parameters. On comparing this study with others in which no association was observed, it remains inconclusive to comment whether vitamin D actually affects the neonatal outcomes.

The criteria for defining optimal vitamin D level and intake during pregnancy remains controversial. could be an important part of public health strategy to 
improve the health of mothers as well as the short and long term outcomes for their off-spring.

\section{References}

1. Haider BA, Bhutta ZA. Multiple-micronutrient supplementation for women during pregnancy. Cochrane Database Syst Rev. 2015 Nov 1;(11):CD004905. doi: 10.1002/14651858.CD004905.

2. Theobald HE. Eating for pregnancy and breast-feeding. $J$ Fam Health Care. 2007;17 (2):45-9.

3. Samuel S, Sitrin MD. Vitamin D's role in cell proliferation and differentiation. Nutr Rev. 2008;66(S):S116-124.

4. Ponsonby AL, Lucas RM, Mei IA. UVR, vitamin D and three autoimmune diseases - multiple sclerosis, type 1 diabetes, rheumatoid arthritis. Photocnem Photobiol. 2005;81:1267-75.

5. Levenson CW, Figueiro SM. Gestational vitamin D deficiency: long- term effects on the brain. Nutr Rev. 2008;66:726-29.

6. Leffelaar ER, Vrijkotte TG, Van EM. Maternal early pregnancy vitamin D status in relation to fetal and neonatal growth: results of the multi-ethnic Amsterdam Born Children and their development cohort. Am J Clin Nutr. 2006;84(2):350-3.

7. Sachan A, Gupta R, Das V, Agarwal A, Awasthi KP, Bharti V. High prevalence of vitamin D deficiency among pregnant women and their newborns in northern India. Am J Clin Nur. 2005;81:1060-4.

8. Kushal M, Magon N. Vitamin D in pregnancy: A metabolic outlook. Indian Journal of Endocrinology and Metabolism. 2013;17:76-82.

9. Bodnar LM, Catov JM, Zmuda JM, Cooper ME, Parrott MS, Roberts JM. Maternal 25(OH)D concentrations are associated with small for gestational age births in whites. J Nutr. 2010;140:999-1006.
10. Sahu M, Bhatia V, Aggarwal A. Vitamin D deficiency in rural girls and pregnant women despite abundant sunshine in Northern India. Clin Endocrinol. 2009;70(5):680-4.

11. Shand AW, Nassr N, Dadselszen P, Innis SM, Gteen TJ. Maternal vitamin D status in pregnancy and adverse pregnancy outcomes in a group of high risk for preeclampsia. Bri J Obstet Gynaecol. 2010;117(13):15938.

12. Gille O. Vitamin D may cut premature birth risk and protect newborn babies. online: http://www.timesonline.co.uk/tol/news/uk/scotland/article 6868729.e. accessed on 2 February 2010.

13. Prentice A, Jarjou L, Golber G, Bennett J, Cole TJ, Schoenmakers I. Maternal plasma 25-hydroxyvitamin D concentration and birthweight, growth and bone mineral accretion of Gambian infants. Acta Paediatr. 2009;98:1360-2.

14. Grundmann M, Hoynck VF. Vitamin D - roles in women's reproductive health?. Reproductive Biology and Endocrinology. 2011;9(1):146.

15. Bowyer L, Catling PC, Diamond T, Homer C, Davis G, Craig ME. Vitamin D, PTH and Calcium levels in pregnant women and their neonates. Clinical Endocrinology. 2009;70:372-7.

16. Morley R, Carlin JB, Pasco JA, Wark JD. Maternal 25hydroxyvitamin $\mathrm{D}$ and parathyroid hormone concentrations and offspring birth size. J Clin Endocrinol Metab. 2006;91:906-91.

How to cite this article: Pandey SK, Pandey HS, Kalra V. Study of serum calcidiol level in pregnancy and its association with fetal outcome. Int J Clin Biochem Res. 2018;5(3):419-422. 